\title{
Discretionary Measures for Hospitality Educators in Improving the English Language Proficiency amongst Hotel Management Students
}

\author{
A. Arun, Ali A. Alalmai
}

\begin{abstract}
The study embarks on understanding the importance of English language skills in the Indian hospitality industry. It explores the specific English language proficiency need among students to overcome their communication inability and the role to be played by the hospitality teachers in improvising their communication skill. The study was conducted among the hoteliers in Chennai a semi structured set of questionnaires were patterned to interview the views of the hoteliers. The findings highlighted the need of the language proficiency in students for their commutative activities and language skill requirements as employee, the methodologies and recommendations to be followed or enhanced strategies in developing the English Language skill among the students.
\end{abstract}

Key Words: English Language, Fluency, Measures, Hotel Management \& Educators.

\section{I.INTRODUCTION}

In the globalized scenario English Language has emerged as the language of business and trade, beside science it has been universally imposed into aviation, computing and tourism. English Language has been spoken extensively in many part of the world as official or co-official language. 1 Effective communication in English language ensures a sense of steadiness to entail the organizational objectives to their individual clients or customers.

Hotel Industry is one among the best ever growing sector generating a good part of revenue to the country's economy. Hotel industry is an important part of the tourism sector, is varied in character as it provide lodgings for the customers the guests, from different part of world with different language, culture and business backgrounds. 2 Hotel industry always plays a major role in creating employment at located localities, it brings in foreign exchanges. It is a mainstay service industry that festive in interaction with customers and develops its business. 3

As communication is the prime approach to reach and serve the guest, English - the global language of the business world is considered the prime quality of acquisition among the employees at hospitality industry. Hotel industry is a service industry with both tangible and intangible products 4 to be marketed, an employees with good communication skill in English Language is more productive and efficient in enhance the profitability of the hotel business as they deal the guest from various foreign countries5. Hereby the hotel management students the future employees of the

Revised Manuscript Received on 14 September, 2019.

A. Arun. Assistant Professor, School of Hotel and Catering Management, Vels Institute of Science Technology and Advanced Studies (VISTAS), Chennai. (Mail Id: arunarticle2016@gmail.com)Mobile: 09884761244

Ali A. Alalmai. Assistant Professor, Community College, Jazan University, Saudi Arabia (Mail id: aaalalmai@jazanu.edu.sa) hospitality, the hotel sector have to be fluent and proficient in English Language.

\section{Objective of the study:}

The main objective of the study is to enumerate the technique to be imposed and improved in enhancing the English Language proficiency among the students in hotel management institutions.

To accomplish the objective the fissure in actual practice at hospitality institutions and the actual communication standard required by the industry are analyzed. Identifying the issues, the set of precautionary measures to be involved in enhancing communication in English Language are enlisted.

\section{MATERIALS AND METHOD}

The study involved the expectations of the hoteliers from hotel management students with regard to communication in English Language and the recommendations or measures to be adopted by the hotel management trainers. The primary data for the study was collected from the qualitative and quantitative opinions of the trainers at the hotel management institutions.

The study initially started with the collection of opinions from the officials at hospitality industry ranging from the middle level to top level of management. The hoteliers are interviewed about their expectations in communication standards in English Language among the hotel management students. Their actual expectations and opinions were considered in formulation of recommendations and methodologies for the trainers at hotel management institutions and colleges.

A questionnaire with a set of 17 questions, excluding the demographic parameters was framed to exhibit the opinions and expectations of the hoteliers. The questions were more oriented towards the hoteliers' opinion about the importance and need for communication skill in English Language among the students and their expectations with regard to their communication in English as an employee in industry. 


\section{Discretionary Measures For Hospitality Educators In Improving The English Language Proficiency Amongst Hotel Management Students}

\section{RESULTS AND DISCUSSION}

The study constitutes the qualitative information from the hoteliers at the top level and middle levels of management. An array of opinions from the hoteliers are being collected, sorted, grouped and recorded for the formulation of recommendation and methodologies to be considered to enhance the communication skill of the hotel management students.

\section{Demographic discussion of Respondents:}

The study was carried out among the hoteliers to exhibit their opinions about the English language proficiency skill in students the future employees of hotels industry. Among the hoteliers, $87.5 \%$ are graduates, $73 \%$ are from the five star categorised hotels and around $88 \%$ of the respondents were executive chefs and managers at top levels of management in all main departments at hotels.

Maximum hoteliers are married and above 40 years and are 10 to 15 years experienced in hotel industry. $67.3 \%$ of employees were working in same hotels for more than 5 years.

Hotelier's opinion about English Language Proficiency among students:

The hoteliers were enquired about their opinion about the need and importance and advantages of English Language proficiency for a student to start up his career at hotel industry. The hoteliers feel that proficiency in English is more important for a student to develop himself in promoting his self respect attitude and confidence level that in turn develops the concern he is engaged in. Predominantly the hoteliers enlisted the following advantageous aspects if an employee is being well versed in English Language.

Hotel industry employs people from any part of the nation or world. English Language acts as a common communicable language among employees and avoids misunderstands and avoids diversities with regard to nation or language.

- A student when initiates his career as an employee at hotel if been fluent and communicable in English Language he is more confident to carry on his job. This confidence improves a self esteem in him as an employee.

Upon the hoteliers opinion the team spirit and coordination aptitude is comparative more in employees with good proficiency in English Language.

- Good proficiency in English Language helps in Good and prompt decision making, planning, budgeting, eminently leads the department and actively carryout the department functions.

- $\quad$ English serves as a main communicable language among the employees it improves the cooperation between the employees at work stations. A fresher with good proficiency in English can understand his superiors or colleagues command and act focused that keeps the work environment more pleasant.

- $\quad$ An active, communicable and confident employees serves the guest more prominently and improves the standard of quality in turn enhances the business and productivity standards.

Discretionary measures to enhance English Language:
Proficiency in English Language is more significant at all the levels of management of the employees at hotels. It acts as a prime quality to serve the guest with utmost satisfaction, co-ordinate, communicate and lead the department at any stage of an employees throughout his career in hotel industry6

Analyzing the opinions from hoteliers the study enumerates a detail note of teaching methodologies and recommendations to be ingeniously applied by the hospitality institutions educators to improve English Language proficiency among the hotel management students.

\section{Teaching through conversations:}

The best ever way to learn a language is practice speaking in respective language thus conversation in English among the hotel management educators and students and following a strict practice to converse in English among the students themselves makes the students well verse in English Language. The hoteliers at recruitment expect their candidates to be good in communication. Among the methodologies of teaching English Language among students conversation is the best and simple way of teaching. Construction of sentences upon the situation is framed out and spoken immediately during conversations7.

\section{Teaching through games:}

Beside other method of classroom teaching, using games to teach language is more recommended as it makes the classroom lively without making the student feel bored8. Different set of games example Who am I and missing information, Giving clues and fishing, whispering games, search games, board games9 etc were used to develop the vocabulary and conversations and also strongly liked by the students.

Hotel management educators can impose these games practices among students and make them understand and learn more vocabularies about ingredients and their uses in cooking, service practices and standard operating procedures etc, as understanding vocabularies and their usages in language helps to develop one in using during the conversations. A game always keeps the students amused, encourages, teaches and improves the fluency of English language among the students. 10

\section{Analysing the Case Studies:}

The students can be provided with situational cases and can be asked to solve particular issues or problems and handle those situations. This method of problem solving approach makes the student to think and act independently.11

Resolving a case study is an integrated method of teaching that always keeps the students active and feel involved12, these methodologies in teaching at hotel management institutions improves the student's quality of communication and problem solving tactics and trains him to act positively during his career at hotel at hotel industry in future. 


\section{Competitions:}

Competition and education is more interrelated13, Conduction of competitions among the students makes them explore the concepts and put forward their ability in it. Competitions like debates and elocutions help the students to possibly construct sentences and enhance their knowledge about language and in turn their studies. Competitions improve a positive attitude of acceptance and build courage to handle a crowd and improving the personality development of students. 14

\section{Creative assignments and role plays:}

Proficiency of English language among the students also depends upon the quality and skill of the teachers who teaches the language. These two facts assigning creative assignment and conduction of the role plays among the proficiency of the educators.

Assigning creative assignment to the students improves the effective learning in students 15 , it improves the research quality among the students a student specializing in food and beverage production can enhance his ability in formulating new recipes etc, it lifts up the possibilities of creating completely new concepts and innovative measures.

Role Play - help in practical usage of languages, it helps in framing conversations and improves the situation handing communication. The hotel management educators can assign make them to act upon the given situations. Role plays improvise the English language proficiency required to handle business situations and make the students an effective decision maker.16

\section{Help from the multimedia:}

The multimedia teachings support learning in the forms of texts, graphs, animations, videos and audios. It integrates both teaching and learning to provide an improved understanding of the language.17 Usage of multimedia in English Language learning arouses student's interest in learning, improves self learning and innovative ability, and increases the subject understanding. 18

The business of hotel industry is more depending upon the foreign visitors hence a fluent and proficient communication improves the guest service and satisfaction in customers. Hereby a proficiency in English language has become a compulsory aptitude in employees at hotel industry. The hospitality institution educators have the responsibility to involve advantageous methodologies in teaching students for their English Language development.

\section{CONCLUSION}

Summing up the opinions of the employees at hotel sector they feel, a good fluency or proficiency in English Language always plays a very important role in handling the guest and co-workers at any level of managements. Hoteliers are not more keen on their syllabus curriculum like poetries, prose or grammars, Beside they prefer a mere proficiency or knowledge in English Language that makes the student feel himself a confident communicator among his employees and serve his guest from any part of the world with an extreme level of confidence. The study also recommends some students depends upon the creativity and language different scene, situation and characterize the students and

discretionary measures for hospitality educators to enhance the communication skill with English Language proficiency.

\section{LIMITATIONS OF THE STUDY}

This study is purely based on the information sourced from the hotelier in and around Chennai hotels. The study is more depended upon the samples, the opinions, perception and expectation of the responded hoteliers may differ upon the demographic parameters.

\section{ACKNOWLEDGEMENT}

The authors exert their opportunity to acknowledge the hoteliers from the hotels at Chennai in providing their valuable opinions and support to carry out the study successfully.

CONFLICT OF INTEREST - Nil

ETHICAL CLEARANCE - Nil.

\section{REFERENCES}

1. Bilal Genç\&ErdoğanBada. English as a World Language in Academic Writing. The Reading Matrix 2010 Volume 10, Number 2, Available from: http://www.readingmatrix.com/articles/sept_2010/bilal_g enc.pdf

2. Svetlana Vukosav\&NevenaĆurčić. The Role of the Hotel Industry in the Economic and Regional Development of Vojvodina. GeographicaTimisiensis, vol. XXII, nr. 2, 2013 (pp. 65 - 73)

3. VikasAcharya. Why English language skills are more compulsory in the Hotel Industry. [Internet] 2015 November 16. [Cited 2018 August 29] Available from: https://www.linkedin.com/pulse/why-english-languageskills-more-compulsory-hotel-industry-acharya

4. DraženMarić, VeljkoMarinković, RadenkoMarić\&DarkoDimitrovski. Analysis of Tangible and Intangible Hotel Service Quality Components. Industrija,2016. Vol.44, No.1, DOI: 10.5937/industrija1-8437.

5. MusaratYasmin, MelaSarkar\& Ayesha Sohail. Exploring English Language Needs in the Hotel Industry in Pakistan: An Evaluation of Existing Teaching Material, Journal of Hospitality \& Tourism Education, $2016.28: 4, \quad 202-213, \quad$ DOI 10.1080/10963758.2016.1226846

6. Arati Prabhu \&PrachiWani. A study of Importance of English Language Proficiency in Hospitality Industry and the Role of Hospitality Educators in Enhancing the Same Amongst the Students. Atithya: A Journal of Hospitality 2015 January. Volume 1 Issue 1. Available from: http://aissmschmct.in/wpcontent/uploads/2016/07/25.pdf.

7. Mr. G. Anburaj, G. Christopher \& Ms. Ni Ming. Innovative Methods of Teaching English Language. IOSR Journal Of Humanities And Social Science (IOSRJHSS) 2014 August. Volume 19, Issue 8, Ver. IV, PP 62 65.

8. AmonratChirandon Dr.

ChonladaLaohawiriyanon\&AnchanaRakthong. The Effects of Teaching English through Games. The 2nd International Conference on Humanities and Social Sciences. Faculty of Liberal Arts, Prince of Songkla University. 2010 April 10. Available from: http://fs.libarts.psu.ac.th/research/conference/proceedings $-2 / 4 \mathrm{pdf} / 006 . p d f$ 
9. BlankaFrydrychovaKlimova. Games in the Teaching of English. Procedia - Social and Behavioral Sciences. 2015 June. Volume 191, Pages 1157-1160.

10. Ali Derakhshan\&ElhamDavoodiKhatir. The Effects of Using Games on English Vocabulary Learning. Journal of Applied Linguistics and Language Research. 2015. Volume 2, Issue 3, pp. 39-47 Available from: www.jallr.ir

11. Akzhan M. Abdyhalykova. Innovative Methods of Foreign Languages Teaching. Indian Journal of Science and Technology,2016 June. Vol 9(22), DOI: 10.17485/ijst/2016/v9i22/95561.

12. Rachel Goh\&Yanping Fang. Improving English language teaching through lesson study: Case study of teacher learning in a Singapore primary school grade level team", International Journal for Lesson and Learning Studies, Vol. 6 Issue: 2, pp.135-150, https://doi.org/10.1108/IJLLS-11-2015-0037

13. Rosely. The Importance of Competition and Its Role in Education. [Internet] 2012 July 2 [Cited 2018 September 4] Available from: http://www.collegequizbowl.org/theimportance-of-competition-and-its-role-in-education/

14. Anna UhlChamot. Language Learning Strategy Instruction: Current Issues and Research. Annual Review of Applied Linguistics, 2005 March Volume 25 pp. 112130. https://doi.org/10.1017/S026719050500006.

15. Veronica J. Austen. The Value of Creative Writing Assignments in English Literature Courses,New Writing, 2005 2:2, 138- 150, DOI: 10.1080/14790720508668953

16. Feng Liu \& Yun Ding. Role-play in English Language Teaching. Asian Social Science. 2009 October Volume 5 No. $10 . \quad$ Available from: http://citeseerx.ist.psu.edu/viewdoc/download?doi=10.1. 1.1013.9714\&rep=rep1\&type $=$ pdf

17. Min Pun. The Use of Multimedia Technology in English Language Teaching: A Global Perspective. Crossing the Border: International Journal of Interdisciplinary Studies 2013 December 15, Volume 1; Number 1; ISSN 23508922

18. Zhang Zhen. The Use of Multimedia in English Teaching. US-China Foreign Language, 2016 March, Vol. 14, No. 3, 182-189 doi:10.17265/15398080/2016.03.002.

\section{AUTHORS PROFILE}

First Author: A. Arun ,Hotel Management Faculty with Master of Philosophy (M.Phil) in Hotel and Catering Management from Vels University, Chennai. Working as an Assistant Professor in Vels Institute of Science Technology and Advanced Studies, published about 25 articles in national and international journals listed in UGC or Scopus Indexed journals including a chapter in an International book. Attended and presented many papers nationally and internationally and also been awarded the best presenter award in an International Conference at Malaysia on September 2019. Awarded the "Best Young Faculty Award" under GRABS AWARDS 2019 from GRAB Educational Trust Chennai on February 2019 and the "Insc Research Excellence Award 2019" under InSc AWARDS from the Institute of Scholars Bangalore, Karnataka

Second Author: Ali A. Alalmai. Assistant professor at Jazan University, Vice Dean for academic affairs at Community college. Phd in Hospitality Administration from Texas Tech University, M.B.A in Hospatitlty with concentration in marketing from Hohnson and Wales

University. 